\title{
DEVELOPING A SECONDARY MATHEMATICS HIGHER ORDER THINKING SKILLS ASSESSMENT (SMHOTSA) INSTRUMENT
}

\author{
Marzita Puteh \\ Faculty of Science and Mathematics, University Pendidikan Sultan Idris; marzita@fsmt.upsi.edu.my \\ Azrul Azwan Mohd Abdul Aziz \\ Faculty of Science and Mathematics, University Pendidikan Sultan Idris, Malaysia; \\ azroy79@gmail.com \\ Nor'ain Mohd Tajudin \\ Faculty of Science and Mathematics, University Pendidikan Sultan Idris, Malaysia; \\ norain@fsmt.upsi.edu.my \\ Mazlini Adnan \\ Faculty of Science and Mathematics, University Pendidikan Sultan Idris, Malaysia; \\ mazlini@fsmt.edu.my
}

\begin{abstract}
This study aims to develop a Secondary High School Thinking Skills Assessment Instrument (SMHOTSA) for Form 1 students and to test the validity and reliability of SMHOTSA instruments developed. This research is a developmental research. The product of this research is to develop SMHOTSA instruments in multiple choice questions and essay test items. In getting a prototype development, this research will be done on the adaptation of the Borg and Gall's model development. The 10 steps Borg and Gall's (1983) model development were adapted into seven developmental steps; (1) research and collecting information, (2) planning, (3) the initial product development, (4) limited testing, (5) the revision of initial product, (6) field testing, and (7) the revision of final product. A total of 100 Form One students from two secondary schools in the District of Kinta, Perak were involved in this study. The validation of assessment instrument is carried out to evaluate the validity of the assessment instrument in the HOTS Form One secondary mathematics test items. The validation is performed in the early stages of product development by three experts on Mathematics Education. The findings show that all experts agree that the content and quality of the item are in line with the content standards, features of HOTS and language-based items and, are suitable for the use in this study. The findings also showed that the value of $\mathrm{V}$ for the calculation of the validity coefficient of SMHOTSA instruments using the formula $\mathrm{V}$ Aiken approaching the value 1. This finding indicates that the SMHOTSA instrument has a high validity. From the two-part analysis conducted on the results of the respondents who answered SMHOTSA's final instrument, it was found that the Spearmen-Brown coefficient of the same length was 0.702. This finding shows that SMHOTSA instruments also have high reliability coefficients. The implication of this study shows that the High School Level Thinking Skills Assessment (SMHOTSA) instrument for Form 1 students is valid and has high reliability.
\end{abstract}

\section{Keywords: Development, Assessment, Instrument, Validity, Reliability}

\section{Introduction}

The Education Curriculum Transformation in the Malaysian Education Development Plan (PPPM) 2013-2025 emphasizes the concept of Higher Order Thinking Skills (HOTS) (MES, 2013) which encourages producing a generation of critical and creative thinkers. The problem faced by teachers is their lack of ability in developing HOTS assessment instruments, and in addition the unavailability of assessment instrument designed specifically for students to practice their higher order thinking skills. This is in accordance with the results of Silverman and Thompson (2008) which stated that 32 mathematics teachers have difficulty to interpret skills of thinking in Bloom's Taxonomy and developing the test items for higher order thinking. HOTS are valued because they are believed to better prepare students for the challenges of adult work and daily life and advanced academic work. Higher order thinking may also help raise the level of standard test scores. A curriculum emphasizing 
HOTS has been found to substantially increase mathematics and reading comprehension scores of economically disadvantaged students (Pogrow, 2005).

Assessment is a crucial instrument in all subjects, especially for mathematics. An assessment provides constructive feedback for teachers as well as students on the effect of teachings and student's abilities. The results also provide motivation and encouragements for students to achieve better. Moreover, assessment can influence learning behavior of the students as they tend to direct their learning activities using the assessment that is conducted by the teacher. The quality of learning outcomes assessment instruments will influence directly in the achievement of student learning outcomes. Therefore, learning outcomes assessment instrument is a crucial strategic decision for teachers and schools in learning outcomes achievement planning, including the implementation of high order thinking skills tests.

However, the issue which occurs at school level is that, the test that are conducted are inclined to only test the memory aspect and lacks in identifying the student's levels of HOTS. The current ability levels of the students in answering HOTS mathematics questions are very weak, where it has not reached the minimum level (Azrul, et al., 2017). The ability of HOTS of the Malaysian students also still low as seen from the TIMSS survey results. One contributing factor, among others, is that students in Malaysia lacks practice in solving problems which measures HOTS, and the problems faced by teachers is the lack of ability to develop the HOTS assessment instrument. The lacking and the unavailability of the assessment instrument designed specifically to practice HOTS is the major problem. Hence, it is of great necessity to develop HOTS assessment instruments, especially for secondary school level. The development of HOTS amongst students will generate: students proficiency in problem solving strategies, increased confidence level of students in learning Mathematics, and learning achievement of students in non-routine problems that require increasing higher order thinking skills (Butkowski, et al., 1994).

Mathematical skill is fundamental in everyday life as they exist in almost every aspect. Thus, they underpin effective learning in all subject areas across the curriculum. Mathematical skill is vital to further progress in a wide range of disciplines and unlocks the doors to employment, helping people to become active citizens in today's society. Results of national and international assessments -PISA and TIMSS in particular - pointed the fact that our students lack in ability to solve problems and the ability of higher thinking order skills (HOTS), as seen from the TIMSS survey results (Ahmad Fauzi \& Aida Suraya, 2009). The problem, which occurs at schools level is that, the test that are conducted, are inclined to only test the memory aspect and lacks in identifying the students' HOTS (Kubiszyn \& Borich, 2013). It is crucial that we should identify the students HOTS as early as possible, especially at the lower secondary school level (Form One) in order for any further action to be taken, especially pedagogically, to help develop and nurture their abilities. Hence, with the development of this Secondary Mathematics Higher Order Thinking Skills Assessment (SMHOTSA) instrument in the form of HOTS mathematics test items for secondary school students, we will be well informed on the students' HOTS ability during the lower secondary level and thus, pedagogical steps can easily be taken by teachers to nourish them.

\section{Experimental Details}

This research is a developmental research. The main objective of this research is to (1) develop Secondary Mathematics Higher Order Thinking Skills Assessment (SMHOTSA) instrument for Form One secondary students, (2) test the validity and reliability of the SMHOTSA instrument that has been developed. The research questions of this research are (1) what is the Secondary Mathematics Higher Order Thinking Skills Assessment (SMHOTSA) test instrument for Form One secondary students? (2) Is the Secondary Mathematics Higher Order Thinking Skills Assessment (SMHOTSA) test instrument for Form One secondary students valid and reliable? The product of this research is to develop SMHOTSA instruments in multiple choice tests and essay test items. In getting a prototype development, this research will be done on the adaptation of the Borg and Gall's model development. The 10 steps Borg and Gall's (1983) model development were adapted into seven developmental steps; (1) research and collecting information, (2) planning, (3) the initial product development, (4) limited testing, (5) the revision of initial product, (6) field testing, and(7) the revision of final product. The validation of assessment instrument is carried out to evaluate the validity of assessment instrument in the HOTS Form One secondary mathematics test items. The validation is performed in the early stages 
of product development by three experts from Mathematics Education Department. The empirical test of HOTS secondary mathematics test item was done by conducting a closed field testing. The developed assessment instruments will pass through two stages. The first stage of assessment was carried out to assess the validity of the assessment instrument conducted by the Mathematics Education Department experts. The second phase assessment conducted was the field testing involving 100 students from two schools, the assessment focused on the characteristics of SMHOTSA test items. The process in this development stage includes the preparation of SMHOTSA test items. A SMHOTSA test item that has been designed will be assessed by the three experts. Then, the revision will be done in order to obtain the initial product of SMHOTSA test items that are ready to be used as limited materials testing. The results of the testing are limited, as a revision to the main product of SMHOTSA test items that are ready, will be used as a field testing. Estimation of reliability coefficient, criteria of difficulty level, differentiator, and alternative distracters will be obtained as the results of field testing and hence the final product of SMHOTSA test items is ready to be used. Product Testing Results Validation by experts will also be conducted to see the contents of the initial product. This validation aims to get input, suggestions for improvements, as well as an assessment of the initial product before conducted the limited testing. The validation activities are carried out by providing initial product text in the form of lattice items and SMHOTSA test items and validation sheet to three experts. Field testing will be conducted to a number of students from various selected schools to initially test the instrument. The data analysis of these limited data and field test will be using classical test theory parameters to determine the quality of a SMHOTSA test item empirically as a basic for revision and assembly of SMHOTSA test item.

The data in this study includes quantitative and qualitative data. These data aimed to give description on the quality of products that is developed. The qualitative data is obtained from the results of the initial product expert validation SMHOTSA test item, while quantitative data is obtained from a SMHOTSA test item product testing. The research instrument that is developed in this research is classified into two types, each of which is used to meet the criteria of validity and reliability. Instrument for measuring the validity via the validation sheet (review test questions) were analyzed qualitatively. Validation review from three aspects: material, construction, and language. These questions were considered valid or worthy based on the expert's assessment. Instrument for measuring the reliability consists two sets of test questions, a multiple choice questions and problem description. SMHOTSA test item is examined individually and the results were analyzed quantitatively to know the estimated coefficient of reliability assessment instruments developed. Data collection techniques used by the researcher are as follows: (1) drafting the instruments that will be used in research, such as HOTS test item, scoring and assessment, (2) determine the validity of the content of the instrument with expert judgement or ask some mathematics education experts to validate the instrument that have been made, (3) do the revision of instruments complies with the suggestions of the validator, (4) testing research instruments, (5) determine the reliability, difficulty level, and distinguishing items, (6) do the revision instrument based on the analysis of the testing result.

\section{Results And Discussion}

This SMHOTSA instrument consists of two sections, Section A which is an objective form and Section B is an essay questionnaire. Section A contains 20 questions while Section B contains 12 questions. The questions in both divisions are mathematics questions or problem solving in HOTS. This SMHOTSA instrument is in the Primary School Achievement Test (UPSR) format and includes all units in the standard curriculum and assessment (DSKP) Mathematics Year 6. This question paper should be answered within two hours and thirty minutes. The two hours thirty-minute duration was applied on expert advice as a result of a pilot study. These questions were developed with reference to the Year 6 Mathematics DSKP as well as the National Year 6 Mathematics textbooks. They were based on the DSKP 6th year mathematics as it can illustrate the mathematics skills they have learned while in elementary school and cover the entire elementary mathematics syllabus. To ensure that this SMHOTSA instrument meets the characteristics of HOTS, the definition of HOTS from the Ministry of Education (MOE) is examined in conjunction with the views of several other experts.

MOE (2013) defines HOTS as the ability to apply knowledge, skills and values in using reasoning and reflexes to solve problems, make decisions, innovatively create. HOTS is normally referred to four top-level Bloom taxonomies; namely application, analysis, synthesis and evaluation. The HOTS categories includes critical thinking, creative thinking, logical thinking, reflective and meta cognitive 
thinking (MOE, 2012). A student is said to have high-level thinking skills when he has mastered four Bloom's top taxonomies and can relate to their existing knowledge to solve complex situations (MOE, 2012; Yee et al., 2012; Gilligan, 2007). Students who have mastered all the featured Bloom's taxonomies can be classified as students who have had KBAT in themselves (Abu Bakar, 2013). Generally, HOTS refers to four top-level Bloom taxonomies namely applying, analyzing, evaluating and creating skills. Therefore, in order to construct items of questions that characterize HOTS, the views and definitions of these experts and thinkers are taken into account in particular to the definition of MOE itself. It is also tailored to the current Malaysian education curriculum that is the Primary School Standard Curriculum (KSSR). Through KSSR, student assessments are based on Mastery Level (TP) i.e. from the level of mastery one to the sixth level of control as Table 1.

Table 1: Mastery Levels for Mathematics Assessment

\begin{tabular}{|c|c|}
\hline Mastery Level & Interpretation \\
\hline $\mathbf{1}$ & Vunnern honin Mathamation \\
\hline $\boldsymbol{P}$ & 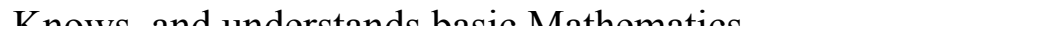 \\
\hline 3 & Knows and understands basic Mathematics including in \\
\hline 4 & $\begin{array}{l}\text { Knows and understands basic Mathematics and able to } \\
\text { calculate in solvino routine evervdav nrohlems }\end{array}$ \\
\hline 5 & $\begin{array}{l}\text { Master and are able to apply the knowledge and Mathematics } \\
\text { skill in solving routine everyday problems using multiple }\end{array}$ \\
\hline 6 & $\begin{array}{l}\text { Master and are able to apply the knowledge and Mathematics } \\
\text { skill in solving routine everyday problems using multiple } \\
\text { strategies creatively and innovatively }\end{array}$ \\
\hline
\end{tabular}

Based on the Mastery Levels for mathematics assessment in KSSR and the views of experts on the definition of HOTS, it is found that mathematical questions characterized by HOTS starts from Level 3 to Level of Mastery 6 level (Marzita, et al., 2017). Hence the process of building question items characterized by HOTS in the instrument SMHOTSA must include Mastery Level 3 to Mastery Level 6. Question items constructed into the SMHOTSA Part A instrument are as in Table 2.

Table 2: Items in SMHOTSA instrument Part A

\begin{tabular}{ccc}
\hline Question & Unit & ML \\
\hline 1 & Numbers and Operations & TP4 \\
2 & Fractions + Numbers and & TP5 \\
& Operations \\
3 & Fractions & TP5 \\
4 & Length + Decimal & TP3 \\
5 & Mass + Decimal & TP5 \\
6 & Percentage + Money & TP4 \\
7 & Percentage + Money & TP5 \\
8 & Percentage + Money & TP5 \\
9 & Time & TP3
\end{tabular}




$\begin{array}{ccc}10 & \text { Time + Fractions } & \text { TP4 } \\ 11 & \text { Space } & \text { TP5 } \\ 12 & \text { Mass + Decimal } & \text { TP6 } \\ 13 & \text { Volume of Liquid + Decimal } & \text { TP4 } \\ 14 & \text { Length + Volume of Liquid }+ & \text { TP6 } \\ & \text { Percentage } & \\ 15 & \text { Mass + Volume of liquid } & \text { TP4 } \\ 16 & \text { Length + Space } & \text { TP4 } \\ 17 & \text { Coordinates } & \text { TP3 } \\ 18 & \text { Ratio and Rating } & \text { TP3 } \\ 19 & \text { Mass + Ratio and Rating } & \text { TP6 } \\ 20 & \text { Data Management } & \text { TP3 }\end{array}$

The question items built in the SMHOTSA Part B instrument are essay questions as in Table 3.

Table 3: Items in SMHOTSA Part B. instrument

\begin{tabular}{|c|c|c|c|}
\hline \multicolumn{2}{|c|}{$\begin{array}{c}\text { Questio } \\
\text { ns }\end{array}$} & Unit & ML \\
\hline 1 & & Numbers + Operations & ТP4 \\
\hline 2 & & Space + Fractions & TP5 \\
\hline \multirow[t]{2}{*}{3} & $\mathrm{a}$ & Fractions & TP5 \\
\hline & $\mathrm{b}$ & Fractions & TP4 \\
\hline 4 & & Mass + Decimal & TP5 \\
\hline 5 & & Mass & TP5 \\
\hline \multirow[t]{2}{*}{6} & $\mathrm{a}$ & Money + Percentage & TP4 \\
\hline & $\mathrm{b}$ & Money + Percentage & TP6 \\
\hline \multirow[t]{2}{*}{7} & $\mathrm{a}$ & Money + Percentage & TP4 \\
\hline & $\mathrm{b}$ & Money + Percentage & TP6 \\
\hline 8 & & Volume of Liquid & TP5 \\
\hline \multirow[t]{2}{*}{9} & $\mathrm{a}$ & Length & TP4 \\
\hline & $\mathrm{b}$ & Length & TP5 \\
\hline \multirow[t]{2}{*}{10} & $\mathrm{a}$ & Mass + Decimal & TP4 \\
\hline & $\mathrm{b}$ & Mass + Fractions & TP6 \\
\hline
\end{tabular}




\begin{tabular}{cccc}
11 & & Space & TP4 \\
12 & $\mathrm{a}$ & Ratio and Rating & TP6 \\
& $\mathrm{b}$ & Ratio and Rating & TP4 \\
\hline
\end{tabular}

The total score for all of these items is based on a percentage with a full score of $100 \%$. Part A represents $\quad 40 \%$ while part B represents $60 \%$.

A pilot study was administered at a national secondary school located in the North Kinta District, Perak. This pilot study was administered to 35 respondents from the same population but not including the study participants. This pilot study is administered through split separation reliability. Aiken and Groth-Marnat (2008) state that internal consistency through split half reliability and alpha coefficients are the best techniques to determine the reliability of an instrument. From the two split analysis carried out, the Spearmen-Brown coefficient of the same length is 0.702. This finding shows that this constructed instrument has high reliability as stated by Othman (2013).

To ensure the validity of the SMHOTSA instrument, the items contained in this instrument have acquired the verification and validity of the content from three experts, two Mathematics Distinguished Teachers (GCM1 and GCM2) and a Chief of Mathematical Committees (KPM3). These three experts evaluate the accuracy of the content of the questions based on the criteria mentioned above by specifying the degree of agreement on each item based on the five-point Likert scale as in Table 4. Response 1 to 3 is considered disagreeable while responses 4 and 5 are considered acceptable.

Table 4: Likert Five Points Scale

\begin{tabular}{cc}
\hline Score & Statement \\
\hline $\mathbf{1}$ & Strongly Disagree \\
$\mathbf{2}$ & Disagree \\
$\mathbf{3}$ & Less Agree \\
$\mathbf{4}$ & Agree \\
$\mathbf{5}$ & Strongly Agree \\
\hline
\end{tabular}

Expert assessments are based on six items namely (1) Instruments built to suit the title (2) Instruments built into the designated questionnaire (3) Instruments built into DSKP are based on the desired level of mastery (4) The arrangement of the item conforms to the construct (5) Clarity of the meanings and descriptions of each criterion (6) Conformity of instruments and feasibility. Further analysis of the SMHOTSA test item items is conducted based on the assessment by experts using the V Aiken formula to calculate the coefficients of the validity of the content. The expert assessment results on SMHOTSA instruments are shown in Table 5.

Table 5: SMHOTSA Instrument Rating By Expert

\begin{tabular}{cccc}
\hline $\begin{array}{c}\text { Ite } \\
\mathbf{m}\end{array}$ & $\begin{array}{c}\text { Mathematic } \\
\text { Distinguishe } \\
\text { d Teacher 1 } \\
\text { (GCM1) }\end{array}$ & $\begin{array}{c}\text { Mathematic } \\
\text { Distinguishe } \\
\text { d Teacher 2 } \\
\text { (GCM2) }\end{array}$ & $\begin{array}{c}\text { Chief of } \\
\text { Mathematic } \\
\text { al } \\
\text { Committees } \\
\text { (KPM3) }\end{array}$ \\
\hline $\mathbf{1}$ & 4 & 5 & 4 \\
$\mathbf{2}$ & 4 & 4 & 4
\end{tabular}




\begin{tabular}{llll}
$\mathbf{3}$ & 5 & 5 & 4 \\
$\mathbf{4}$ & 5 & 5 & 4 \\
$\mathbf{5}$ & 4 & 4 & 5 \\
$\mathbf{6}$ & 5 & 4 & 4 \\
\hline
\end{tabular}

Table 6 shows the percentage of validation of experts appointed on each item of SMHOTSA instrument evaluation form. Conclusively, all experts agree that the content and quality of the item are in line with the content standard, the characteristics of KBAT items and language adjustments and are suitable for use in this study.

Table 6: Percentage Approval of SMHOTSA Instrument

\begin{tabular}{|c|c|c|c|}
\hline & GCM1 & GCM2 & KРM3 \\
\hline $\begin{array}{c}\text { Approva } \\
1\end{array}$ & $\begin{array}{l}100 \% \\
(5 / 5)\end{array}$ & $\begin{array}{c}100 \% \\
(5 / 5)\end{array}$ & $\begin{array}{l}100 \% \\
(5 / 5)\end{array}$ \\
\hline
\end{tabular}

Further analysis of the SMHOTSA test item items is conducted based on the assessment by experts using the V Aiken formula to calculate the coefficients of the validity of the content. Formula V Aiken is as Figure 1.

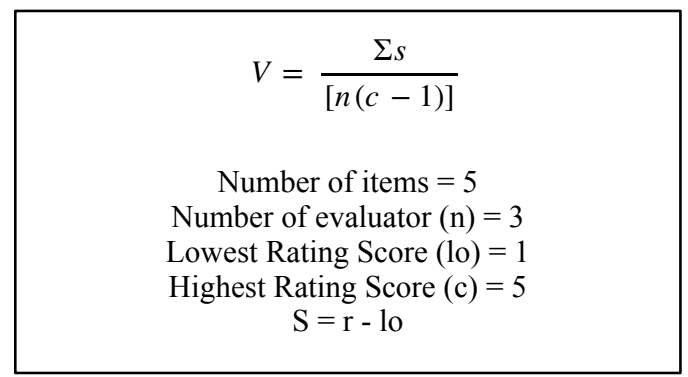

Figure 1: V Aiken Computation Formula

The findings of the V Aiken computational formula for the validity of the evaluation of SMHOTSA instruments of the three experts are as Table 7.

Table 4.8: Findings on the Validity of Expert Rating using V Aiken Formula.

\begin{tabular}{|c|c|c|c|c|c|c|c|c|c|c|c|c|}
\hline $\begin{array}{c}\mathbf{E} \\
\text { va }\end{array}$ & $\begin{array}{r}\text { Ite } \\
1\end{array}$ & & Ite & & $\begin{array}{r}\text { Iter } \\
\mathbf{3}\end{array}$ & & $\begin{array}{r}\text { Ite } \\
4\end{array}$ & & $\begin{array}{r}\text { Iter } \\
5\end{array}$ & & $\begin{array}{r}\text { Ite } \\
6\end{array}$ & \\
\hline $\begin{array}{l}\text { at } \\
\text { or }\end{array}$ & $\begin{array}{c}\text { Sc } \\
\text { or } \\
\text { e }\end{array}$ & $\mathbf{S}$ & $\begin{array}{c}\text { Sc } \\
\text { or } \\
\text { e }\end{array}$ & $\mathbf{S}$ & $\begin{array}{c}\text { Sc } \\
\text { or } \\
\text { e }\end{array}$ & $\mathbf{S}$ & $\begin{array}{c}\text { Sc } \\
\text { or } \\
\text { e }\end{array}$ & $\mathbf{S}$ & $\begin{array}{c}\text { Sc } \\
\text { or } \\
\text { e }\end{array}$ & $\mathbf{S}$ & $\begin{array}{l}\text { Sc } \\
\text { or } \\
\text { e }\end{array}$ & $\mathbf{S}$ \\
\hline 1 & 4 & 3 & 4 & 3 & 5 & 4 & 5 & 4 & 4 & 3 & 5 & 4 \\
\hline 2 & 5 & 4 & 4 & 3 & 5 & 4 & 5 & 4 & 4 & 3 & 4 & 3 \\
\hline
\end{tabular}




\begin{tabular}{|c|c|c|c|c|c|c|}
\hline 3 & 43 & 43 & 43 & 43 & 54 & 5 \\
\hline$\Sigma s$ & 10 & 9 & 11 & 11 & 10 & 11 \\
\hline V & 0.83 & 0.75 & 0.92 & 0.92 & 0.83 & 0.92 \\
\hline
\end{tabular}

The findings show the $\mathrm{V}$ value of all six items is approaching to the value of 1 .

To determine the SMHOTSA instrument has high reliability, the split half reliability method is done for the answers of 100 respondents SMHOTSA final instruments. Through this method, the test score of the 100 pupils is divided into two parts, the first part is to evaluate score for the odd question while the second part is the score for the even numbered questions. Then the two side reliability tests are carried out. From the two split analysis carried out, the Spearmen-Brown coefficient of the same length is 0.732 . This finding shows that this newly constructed instrument has high reliability as stated by Othman (2013).

\section{Conclusion}

Through this study, it is found that the SMHOTSA instrument is an instrument consisting of two parts, Section A which is an objective form and Section B which is essay question form. Section A contains 20 questions while Section B contains 12 questions. The questions in both sections are mathematical questions or problem solving in KBAT form. This SMHOTSA instrument is in UPSR format and includes all units in the standard curriculum and assessment (DSKP) Mathematics Year 6. This question should be answered within two hours and thirty minutes. The two hours thirty-minute duration was applied on expert advice as a result of a pilot study. These questions were developed with reference to the Year 6 Maths DSKP as well as the National Year 6 Mathematics textbooks. To cater for the characteristics of HOTS, these questionnaire items begin with at least the level of three domains (TP3) to the level of control of six (TP6) according to KSSR format. The findings also show the value of $\mathrm{V}$ for the calculation of the validity coefficient of SMHOTSA instruments using the formula V Aiken is approaching the value 1. From the two split analysis conducted, the SpearmenBrown coefficient of the same length is 0.702 .

\section{References}

Abu Bakar Nordin. (2013). Kurikulum Ke arah Penghasilan Kemahiran Berfikir Kritis, Kreatif dan Inovatif. Jurnal Kurikulum dan Pengajaran Asia Pasifik, 1, 10-18

Ahmad Fauzi, M.Y \& Aida Suraya, M.Y. (2009). Pendidikan Matematik \& Aplikasi Teknologi, Penerbit Universiti Putra Malaysia, Serdang

Azrul Azwan Mohd Abdul Aziz, Marzita Puteh, Nor'ain Mohd Tajudin \& Mazlini Adnan (2017). Pupils Achievement Towards Higher Order Thinking Skills Mathematics Questions With Bar Model Method. Science International (Lahore) Jurnal, 29(4), 733 - 736

Butkowski, J., Corrigan, C., Nemeth, T., \& Spencer, L. (1994). Improving student higher order thinking skills in mathematics. Theses, Mathematics Education Research. Saint Xavier University-IRI, Field-Based Master's Program.

Gilligan, M.E. (2007). Traditional Versus Alternative Assessments: Which Type Do High School Teachers Perceive As Most Effective In The Assesment of Higher-Order Thinking Skills?, Thesis PhD. Saint Louis University.

Kubiszyn, T. \& Borich, G. D. (2013). Educational testing \& measurement. Classroom application and practice, (10th ed.). John Wiley \& Sons, Inc, New York

Malaysian Examination Syndicate (MES). (2013). Pentaksiran kemahiran berfikir aras tinggi, Ministry of Education Malaysia, Kuala Lumpur

Marzita Puteh, Nor'ain Mohd Tajudin, Mazlini Adnan Azrul Azwan Mohd Abdul Aziz (2017). The Utilisation Of Bar Model Method In Year 5 Mathematics Learning Based On HOTS. International Conference on Business and Social Sciences (ICBSS) Conference, Seoul, Korea (south) 14 -15th April.

Ministry of Education Malaysia (MOE). (2013). Program Kemahiran Berfikir Aras Tinggi: Konsep KBAT, Ministry of Education Malaysia, Putrajaya

Ministry of Education Malaysia (MOE). (2012). Kemahiran Berfikir Aras Tinggi dalam Sains dan Matematik (HOTSSM), Ministry of Education Malaysia, Putrajaya 
Othman Talib. (2013). Asas Penulisan Tesis Penyelidikan \& Statistik (Cetakan Pe.), Universiti Putra Malaysia, Kuala Lumpur.

Pogrow, Stanley. (2005). "HOTS revisited: A thinking development approach to reducing the learning gap after grade 3." Phi Delta Kappan, 87, 64-75.

Silverman, J. \& Thompson, P., Towards. (2008). A framework for the development of mathematical knowledge for teaching, Journal of Mathematics Teacher Education, 11(6), 499 - 511

Yee, M.H., Jailani Md Yunos, Widad Othman, Razali Hassan, Tee, T.K. \& Mimi Mohaffyza Mohamad. (2012). The needs analysis of learning higher order thinking skills for generating idea. Procedia - Social and Behavioral Sciences, 59, 197-203 